\title{
Infographic: Positioning In Macular hole Surgery (PIMS) trial
}

\author{
Nikolaos Tzoumas $\mathbb{D}^{1} \cdot$ Declan C. Murphy $^{1} \cdot$ Alexander Mehta $\mathbb{D}^{1} \cdot$ Islam Mostafa $^{1} \cdot$ Salman N. Sadiq ${ }^{1} \cdot$

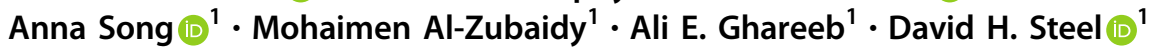

Received: 20 March 2021 / Revised: 31 March 2021 / Accepted: 13 April 2021 / Published online: 26 May 2021

(c) The Author(s) 2021. This article is published with open access

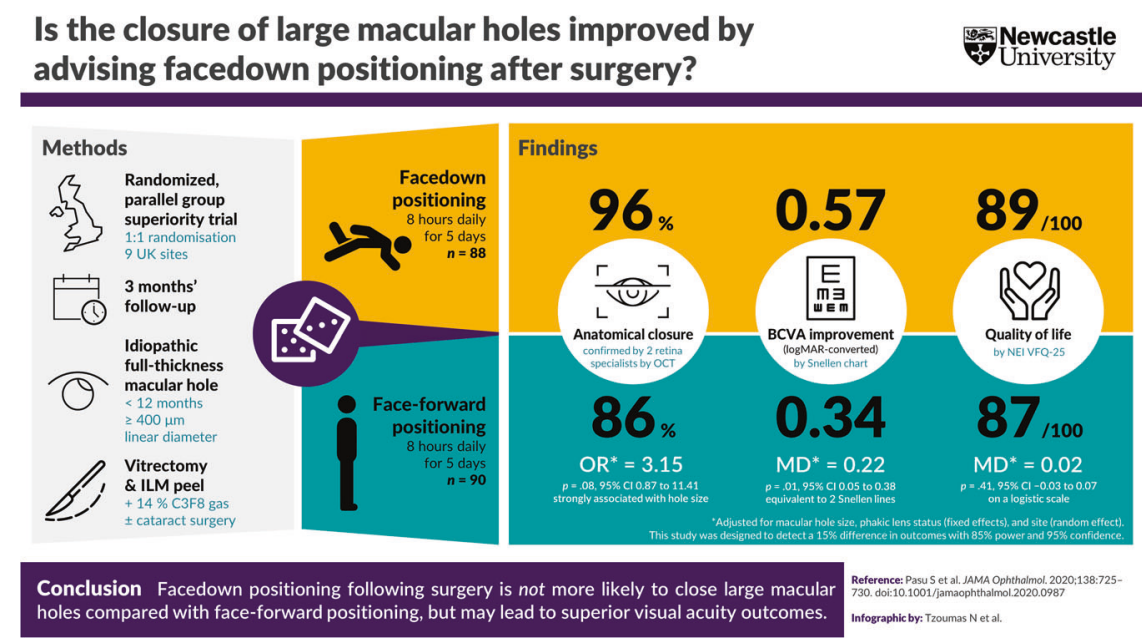

Fig. 1 The Positioning In Macular hole Surgery (PIMS) trial showed that facedown positioning following surgery is not more likely to close large full-thickness macular holes compared to face-forward positioning, but may result in a modest benefit in visual acuity outcomes at three months. BCVA best-corrected visual acuity, C3F8 perfluoropropane, CI confidence interval, ILM inner limiting membrane, MD mean difference, NEI VFQ-25 National Eye Institute Visual Function Questionnaire 25, OCT optical coherence tomography, OR odds ratio, UK United Kingdom.

\section{Compliance with ethical standards}

Conflict of interest The authors declare no competing interests.

Publisher's note Springer Nature remains neutral with regard to jurisdictional claims in published maps and institutional affiliations.

Open Access This article is licensed under a Creative Commons Attribution 4.0 International License, which permits use, sharing, adaptation, distribution and reproduction in any medium or format, as long as you give appropriate credit to the original author(s) and the source, provide a link to the Creative Commons license, and indicate if changes were made. The images or other third party material in this article are included in the article's Creative Commons license, unless indicated otherwise in a credit line to the material. If material is not included in the article's Creative Commons license and your intended use is not permitted by statutory regulation or exceeds the permitted use, you will need to obtain permission directly from the copyright holder. To view a copy of this license, visit http://creativecommons. org/licenses/by/4.0/.

David H. Steel

david.steel@ncl.ac.uk

1 Biosciences Institute, Newcastle University, Newcastle upon Tyne, UK 